\title{
DZIAŁALNOŚĆ RADY KSIĄŻKI W POLSCE W LATACH 1937-1939
}

Geneza powstania stowarzyszenia, statut, formy działalności, zasady finansowania. Formy pracy stosowane przez Radę Książki: ankieta dotycząca motywów kupowania książek, listy książek, bony książkowe, akcja „O jedną książkę więcej!”, konkursy.

SŁOWA KLUCZOWE: Rada Książki, II Rzeczpospolita, książka, propaganda książki, czytelnictwo, księgarstwo, rynek wydawniczy, rynek książki, Polskie Towarzystwo Wydawców Książek, Związek Księgarzy Polskich

\section{WSTĘP}

Po odzyskaniu niepodległości w 1918 roku w Polsce doszło do zmian politycznych, gospodarczych, społecznych i kulturalnych. Nowa sytuacja wpłynęła także na rynek książki, zmieniając funkcje samej książki i instytucji związanych z jej produkcją i rozpowszechnianiem. W nowej rzeczywistości książka miała pełnić rolę jednego z głównych instrumentów odbudowy Polski. Była narzędziem $\mathrm{w}$ walce $\mathrm{z}$ analfabetyzmem, przyczyniała się do upowszechniania oświaty, popularyzowała nowe idee, włączając się w ten sposób w działania na rzecz odbudowy państwowości i tożsamości narodowej Polaków. Powstały wówczas nowe firmy wydawniczo-księgarskie, biblioteki, organizacje społeczno-kulturalne, a do grona osób zajmujących się książką dołączyli ludzie, dla których produkcja i rozpowszechnianie słowa drukowanego nie były już misją i walką o zachowanie polskości, a stały się zwykłym biznesem. Poza tym należy pamiętać o rozszerzeniu się społecznego zasięgu książki, która swoim wpływem zaczęła obejmować nowe grupy odbiorców. Ówczesny rynek książki charakteryzowała niestabilność, czego 
przykładem może być efemeryczny charakter wielu firm wydawniczo-księgarskich. Trudność w utrzymaniu się na rynku wynikała w znacznej mierze z problemów finansowych. Powodem było małe zainteresowanie książką w społeczeństwie lub brak środków na jej zakup w niektórych środowiskach. Niekorzystna sytuacja powodowała antagonizmy wśród ludzi zajmujących się książką, którzy próbowali zadbać głównie o własne interesy. Pomimo opisanej wyżej sytuacji wydawcy i księgarze paradoksalnie nie prowadzili szeroko zakrojonych działań propagandowych, tłumacząc się brakiem pieniędzy i nikłym zainteresowaniem sprawami książki ze strony prasy.

W dwudziestoleciu międzywojennym podejmowano próby akcji promocyjnych o szerszym zasięgu, takie jak: miesiąc książki, tydzień książki, święto książki czy dosyć spektakularna akcja z 1927 roku — organizacja pochodu pod nazwą „Egzekucja ciemnoty”. Na pewno należy wspomnieć o działaniach Komitetu Propagandy Czytelnictwa, powołanego z inicjatywy Związku Księgarzy Polskich (dalej: ZKP), a także o licznych akcjach inicjowanych przez organizacje społeczno-oświatowe.

Celem niniejszego artykułu jest przedstawienie działalności polskiej Rady Książki (dalej: RK) w latach 1937-1939. Omówione zostaną geneza powstania tej organizacji, statut, formy działalności, zasady finansowania. Głównym tematem będą formy pracy stosowane przez RK: ankieta dotycząca motywów kupowania książek, listy książek, bony książkowe, akcja „O jedną książkę więcej!” oraz konkursy. W celu zebrania i opracowania materiału posłużono się metodą analizy źródeł oraz analizy i krytyki piśmiennictwa.

W literaturze przedmiotu brakuje syntetycznych opracowań dotyczących działalności RK w dwudziestoleciu międzywojennym. Jedynym większym objętościowo tekstem na ten temat jest artykuł Jana Muszkowskiego z 1947 roku, opublikowany w „Przeglądzie Bibliotecznym”. W nim ogólnie opisano funkcjonowanie RK przed wojną, traktując tę kwestię jako wstęp do szczegółowego omówienia działalności tego stowarzyszenia po wojnie (Muszkowski, 19471951, s. 380-381). O idei powołania RK w Polsce i działalności zagranicznych rad książki traktował tekst Jakuba Mortkowicza (1926). W zbiorach bibliotecznych pozostały nieliczne dokumenty wytworzone przez tę organizację: statut (Statut, 1937), sprawozdanie z działalności za okres od stycznia 1937 do maja 1938 roku (Sprawozdanie z działalności Rady Książki, 1938), listy książek nr 1-8 (A.P., 1939a, 1939b; H.M., 1939; L.Z., 1938a, 1938b; P.H., 1938; W.P., 1939; W.W., 1939) oraz plakat przygotowany z okazji akcji „O jedną książkę więcej!” (Piotrowski, 1938). Według ustaleń J. Muszkowskiego w trakcie pożaru Warszawy w 1944 roku przepadły pozostałości nakładu sprawozdania RK, statutu i wykazów książek, a także materiały dotyczące „Tygodnia książki” z 1933 roku, które przekazała Radzie Polska Akademia Literatury. Podobny los spotkał materiały zebrane 
w wyniku ogłoszonej przez RK ankiety (Muszkowski, 1947, s. 142). Interesujące źródło stanowią wzmianki w ówczesnej prasie. Najwięcej informacji można odnaleźć w „Przeglądzie Księgarskim”, ponadto teksty o RK pojawiały się również w „Przeglądzie Bibliotecznym”, „Bibliotekarzu”, „Kurierze Bibliofilskim”, a także w prasie codziennej, między innymi w „Kurierze Warszawskim”, czy w pismach społeczno-kulturalnych, na przykład w „Obronie Kultury” czy „Kobiecie w Świecie i w Domu".

\section{GENEZA POWSTANIA I ZASADY FUNKCJONOWANIA STOWARZYSZENIA}

Przykładem z zagranicy, który stał się bodźcem do utworzenia polskiej RK, była Narodowa Rada Książki - organizacja powstała w 1925 roku w Anglii. Jej celem była propaganda czytelnictwa i rozpowszechniania książek. Należało do niej 78 wydawców, 179 księgarzy, 47 autorów i 99 miłośników książki. Rada zajmowała się wydawaniem bibliografii ogólnych i specjalnych (między innymi w 1925 roku wydano bibliografię 100 najlepszych dzieł geograficznych; w 1927 roku zapowiedziano wydanie kilku publikacji pomocniczych dla księgarstwa sortymentowego: spis książek o ówczesnym Egipcie, Niemczech i Stanach Zjednoczonych, Londynie; o książkach i czytaniu; współczesnych biografii, książek o marynarce oraz zestawienie małych bibliotek domowych po pięć funtów każda), współpracowała z Ligą Narodów i organizacjami naukowymi, wydawała komunikaty o czytelnictwie, urządzała szereg odczytów, a także doroczny uroczysty bankiet. Jako przykład działań angielskiej rady można wskazać stworzenie filmu omawiającego dzieje książki, który ukazywał ją z różnych punktów widzenia, na poszczególnych etapach produkcji — od rękopisu do umieszczania na półce w księgarni. W 1938 roku na łamach „Przeglądu Księgarskiego” zapowiadano okazałą i pierwszą tego typu imprezę zorganizowaną z inicjatywy tamtejszej rady książki — narodowe targi książki angielskiej. Zaplanowano je w terminie 4-21 listopada 1938 roku i miały być one połączone z wystawą książki angielskiej. W 1937 roku (nieco później niż w Polsce) powołano podobną instytucję we Francji. W obydwu przypadkach były to organizacje o charakterze społecznym, które miały na celu promocję zagrożonej kryzysem książki. Różniły się one zakresem i sposobem działania. Rada francuska kładła nacisk na sytuację materialną pisarzy, działając w ich obronie i na rzecz ich interesów. W Anglii skupiono się przede wszystkim na propagandzie księgarskiej. Warto też zwrócić uwagę, że organizacje o podobnym charakterze, działające na rzecz książki, zrzeszające różne środowiska (między innymi wydawców, papierników) istniały w Norwegii, Holandii, Niemczech, Włoszech ((F.B.), 1937; Mortkowicz, 1926; Muszkowski, 1947, s. 141; P., 1927; (PIL), 1938; Rada Książki, 1937a, s. 66; Rada Narodowa Książki, 1927). 
Pomysł powołania w Polsce Rady Narodowej Książki zgłosił w październiku 1926 roku na II Zjeździe Bibliofilów w Warszawie Jakub Mortkowicz, argumentując taką potrzebę kryzysem czytelnictwa w Polsce. Podawał on przy tym przykłady promocji książki i czytelnictwa w Europie i Stanach Zjednoczonych oraz rozwiązania zastosowane na zagranicznych rynkach księgarsko-wydawniczych. W jego opinii w Polsce odczuwalny był wtedy brak instytucji, która stawiałaby „sprawę książki ponad antagonizmami zainteresowanych”. Miał na myśli nieporozumienia pomiędzy: autorami a wydawcami, wydawcami a sortymentystami, wydawcami a papiernikami i drukarzami, księgarzami a nauczycielami, organizacjami oświatowo-kulturalnymi a czytelniami. Mortkowicz uważał, że konieczne jest stworzenie nowej instytucji, dla której najważniejsze byłoby dobro i rozwój książki — najistotniejszego elementu życia kulturalnego. Zjazd przyjął wniosek, uznając konieczność powołania organizacji, która zajęłaby się sprawą produkcji, obiegu i czytelnictwa książki w Polsce. W tym celu wybrano specjalną komisję, która miała się zająć utworzeniem Rady Narodowej Obrony Książki Polskiej (Mortkowicz, 1926; Rada Książki, 1937b).

Jednak oprócz deklaracji nie podjęto żadnych działań mających na celu powstanie takiej organizacji. Pierwsze wzmianki o spotkaniach zainteresowanych kół pojawiły się w prasie dopiero w 1936 roku. Wówczas odbyło się w Warszawie zebranie z udziałem księgarzy, bibliotekarzy, świata literackiego i dziennikarzy, którego głównym tematem było powołanie w Polsce Rady Narodowej Książki. Nie zapadły na nim jednak żadne konkretne decyzje, postanowiono jedynie dalej dyskutować ten temat w szerszym gronie, między innymi planowano rozszerzenie grona zaangażowanych w sprawę o przedstawicieli organizacji oświatowych i społecznych (Ad.L.S., 1936). W 1936 roku Polskie Towarzystwo Wydawców Książek (dalej: PTWK) zorganizowało między kwietniem a listopadem serię konferencji, na których powoli powstawała koncepcja polskiej rady książki. Do współpracy zaproszono następujące organizacje: Związek Zawodowy Literatów Polskich, Polską Akademię Literatury, Polski Oddział PEN Clubu, Towarzystwo Literatów i Dziennikarzy Polskich, Zrzeszenie Beletrystów Polskich, Związek Autorów Dramatycznych, Związek Autorów i Kompozytorów Scenicznych, Związek Bibliotekarzy Polskich (dalej: ZBP), ZKP. Na zorganizowanej 19 listopada 1936 roku konferencji ustalono wytyczne dotyczące statutu stowarzyszenia i powołano trzyosobową komisję do przygotowania jego projektu (Muszkowski, 1947, s. 141; Sprawozdanie z działalności Rady Książki, 1938, s. 3-4).

Zebranie organizacyjne RK odbyło się 27 stycznia 1937 roku$^{1}$. W jego trakcie przedyskutowano i przyjęto projekt statutu, powierzając zarządowi przedstawienie go władzom do zatwierdzenia (Rada Książki, 1937a; Sprawozdanie z działal-

${ }^{1}$ W dostępnych źródłach podawana jest także inna data -25 stycznia. 
ności Rady Książi, 1938, s. 4). Wybrano zarząd w składzie: prezes August Zaleski (były minister spraw zagranicznych); wiceprezes Jan Parandowski; sekretarz Jan Piątek; skarbnik Mieczysław Rulikowski; członkowie: Wacław Gebethner, Zdzisław Kleszczyński, Wanda Melcer, Michał Rusinek, Melchior Wańkowicz. Dwa wakujące miejsca w zarządzie mieli zająć delegat ZBP oraz przedstawiciel jednej $\mathrm{z}$ niereprezentowanych dotąd $\mathrm{w}$ tym gremium organizacji zawodowych - papierniczej lub graficznej. 27 lutego 1937 roku na posiedzeniu Rady ZBP wybrano Wacława Borowego na przedstawiciela tej organizacji do RK. Drugie miejsce pozostało nieobsadzone w okresie sprawozdawczym (czyli od stycznia 1937 roku do maja 1938 roku). Na stanowisko kierownika (dyrektora) biura RK powołano Jana Muszkowskiego, a siedziba stowarzyszenia mieściła się tymczasowo w lokalu PTWK przy ulicy Zielnej 17 m. 8 (Rada Książki, 1937a; Rada Książki, 1937b; Rada Związku Bibliotekarzy Polskich, 1938, s. 75; Sprawozdanie z działalności Rady Książki, 1938, s. 4; Sprawozdanie Zarządu Głównego ZKP, 1937, s. 64). Jego późniejszy adres, umieszczany na wszystkich drukach, to ul. Koszykowa 6a.

23 marca 1937 roku RK została wpisana jako stowarzyszenie (związek) do rejestru stowarzyszeń i związków Komisariatu Rządu m.st. Warszawy pod numerem 1009. Zgodnie ze statutem mogła ona działać na terenie całej Rzeczpospolitej i Wolnego Miasta Gdańska, a w razie potrzeby również w innych krajach. Siedzibą RK była Warszawa (Statut, 1937, s. 3).

Cele statutowe organizacji były następujące: propaganda książki polskiej w kraju i za granicą oraz opieka nad nią; krzewienie czytelnictwa i kultury książki; prowadzenie badań nad książką, wykorzystywanie tej wiedzy w praktyce i jej upowszechnianie w społeczeństwie; doskonalenie metod produkcji i sprzedaży książki; koordynacja polityki i działalności grup zawodowych związanych z książką; rozwój środków propagandy i reklamy książki; zwalczanie wydawnictw pornograficznych i szkodliwych oraz wszystkie działania związane z książką, czytelnictwem i przemysłem wydawniczym. Jako formy działalności wskazano w statucie między innymi: tworzenie kół w Polsce i za granicą, prowadzenie biura, poradni; zakładanie instytutów badawczych, muzeów, szkół, kursów; organizowanie zjazdów, konferencji, odczytów; urządzanie konkursów, przyznawanie nagród, udzielanie stypendiów; przygotowywanie wystaw, wydawanie katalogów i plakatów oraz publikacji, prowadzenie akcji prasowej i reklamowej (Statut, 1937, s. 4-5).

Przewidziano cztery kategorie członków RK: honorowych, wspierających, zwyczajnych i nadzwyczajnych. $\mathrm{O}$ ich przyjęciu decydował zarząd stowarzyszenia w tajnym głosowaniu; wyjątek stanowili członkowie honorowi, którzy byli mianowani przez walne zgromadzenie. Członkiem wspierającym mogła być osoba fizyczna lub prawna, która wpłaciła jednorazowo co najmniej 500 złotych lub zobowiązała się do uiszczania składki rocznej w wysokości co najmniej 100 złotych. Członkami zwyczajnymi mogli zostać zawodowi pracownicy książki (literaci, 
graficy, wydawcy, księgarze, bibliotekarze, drukarze, introligatorzy itp.) oraz pracownicy instytucji i firm związanych z książką. W tym przypadku składka roczna od osób fizycznych wynosiła dziesięć złotych, a firmy i instytucje musiały wpłacić wpisowe w wysokości 50 złotych. Osoby sympatyzujące z celami stowarzyszenia zaliczano do kategorii członków nadzwyczajnych (roczna składka - pięć złotych); nie przysługiwało im prawo wyborcze ani prawo głosu decydującego w obradach. Członków honorowych mianowano spośród osób zasłużonych dla książki lub RK. Uchwała musiała być w tym przypadku podjęta jednogłośnie. Wykreślenie z listy członków następowało: na własne żądanie, w przypadku ponad półrocznego zalegania z uiszczaniem składek lub „w przypadku spełnienia czynu nieetycznego lub godzącego w interesy Stowarzyszenia" (Statut, 1937, s. 5-7). Władze stowarzyszenia składały się z walnego zgromadzenia (zwoływanego raz w roku), zarządu (liczącego jedenaście osób i wybieranego na trzyletnią kadencję), komisji rewizyjnej (złożonej z trzech członków, wybieranych na trzyletnią kadencję). Jedyne informacje o liczbie członków RK pochodzą ze sprawozdania za okres od stycznia 1937 roku do maja 1938 roku. W tym czasie do stowarzyszenia przyjęto 74 członków (w tym: czternastu wspierających, 57 zwyczajnych i trzech nadzwyczajnych), a ubyły dwie osoby ${ }^{2}$ (Sprawozdanie z działalności Rady Książki, 1938, s. 5).

Zgodnie ze statutem majątek RK mógł składać się z: nieruchomości, ruchomości, funduszu obrotowego (to jest wpłat członków, imprez dochodowych), darowizn, zapisów i innych funduszy specjalnych. Według J. Muszkowskiego stowarzyszenie miało skromne środki finansowe, mając na uwadze prowadzenie przez nie działań propagandowych. Rada dysponowała funduszem pochodzącym z: wpłaty PTWK, składek firm wydawniczo-księgarskich (w wysokości zgodnej ze statutem). Sprawozdanie rachunkowe na dzień 31 grudnia 1937 roku opiewało na kwotę 2655 złotych i 14 groszy. Wysokość tej kwoty świadczyła o trudnościach finansowych, z jakimi musiała mierzyć się RK w pierwszym okresie swej działalności. Na początku 1938 roku organizacji udało się pozyskać większe kwoty od firm i instytucji. Rozmowy ze Związkiem Papierni Polskich (dalej: ZPP) zaowocowały przystąpieniem tej organizacji do RK. Przedstawiciel ZPP został członkiem zarządu RK, wpłacając przy tym dziesięć tysięcy złotych. W związku z groźbą wojny Radzie odmówiono przyznania dotacji na następny rok. Brak funduszy spowodował, że stowarzyszenie przerwało działalność już na parę miesięcy przed wybuchem walk. Rada nie miała środków nawet na wypłacenie pensji dwóm osobom z personelu (Muszkowski, 1947, s. 142; Sprawozdanie z działalności Rady Książki, 1938, s. 31-32).

2 Prawdopodobnie dane te dotyczą dwóch członków, którzy wtedy zmarli - Bolesława Koskowskiego i Zdzisława Kleszczyńskiego. 
Na początku funkcjonowania stowarzyszenia próbowano określić najpilniejsze potrzeby środowisk związanych z książką. Organizacje wchodzące w skład Rady miały zgłaszać postulaty do realizacji. Dla kół literackich najważniejsze były: zorganizowanie akcji zmierzającej do zwiększenia zasięgu książki; uchwalenie ustawy bibliotecznej; poprawa warunków pracy pisarzy; poparcie dla merytorycznej i bezstronnej krytyki oraz ochrona języka polskiego. PTWK zaproponowało: rejestrację przedsiębiorstw wydawniczych; zrównanie książki z prasą periodyczną w zakresie podatków ulg pocztowych i kolejowych; zracjonalizowanie subwencji na wydawnictwa $\mathrm{z}$ funduszy publicznych; nowelizację ustawy o nieuczciwej konkurencji. ZKP za najistotniejszą kwestię uznał decentralizację zakupów książek dla urzędów oraz instytucji państwowych i samorządowych (zaopatrywanie się w miejscowych księgarniach i zniesienie obowiązku ogłaszania przetargów na dostawę książek). Uzgodnienie rejestracji bibliograficznej w ramach porozumienia między Biblioteką Narodową a organizacjami wydawców i księgarzy było z kolei postulatem ZBP. W celu rozważenia tych propozycji i ich realizacji na zebraniu, które odbyło się 14 czerwca 1937 roku, powołano specjalne komisje w ramach RK: komisję do spraw bieżącej rejestracji bibliograficznej i komisję do spraw propagandy książek w prasie ${ }^{3}$ (Muszkowski, 1947, s. 142-143; Sprawozdanie z działalności Rady Ksiązki, 1938, s. 7-11, 32).

Na walnym zgromadzeniu członków RK, które miało miejsce 31 maja 1938 roku, zatwierdzono jedyne sprawozdanie z działalności stowarzyszenia za okres od stycznia 1937 roku do maja 1938 roku i zdecydowano się ogłosić je drukiem. Opracowano plan dalszej pracy Rady, który zakładał między innymi: organizację akcji ogłoszeniowej w prasie; urządzenie jesienią „Tygodnia książki” na wzór podobnej imprezy zorganizowanej w 1933 roku z inicjatywy Ministerstwa Wyznań Religijnych i Oświecenia Publicznego; wprowadzenie bonów na zakup książek; opracowanie materiałów do ankiety w sprawie motywów nabywania książek; ogłaszanie konkursów; stałe publikowanie wydawnictw propagandowych itp. Wybrano wówczas także nowy zarząd RK w składzie: August Zaleski (prezes), Jan Parandowski (wiceprezes), Jan Piątek (sekretarz), Mieczysław Rulikowski (skarbnik) oraz członkowie: Wacław Borowy, Artur Górski, Zofia Kossak, Wanda Melcer, Stefan Pomarański, Michał Rusinek, Kazimierz Skarżyński, Adam Szymański, Melchior Wańkowicz (Sprawozdanie z działalności Rady Książki, 1938, s. 32; Z Rady Książki, 1938b).

${ }^{3} \mathrm{Na}$ walnym zgromadzeniu członków RK powołano przewodniczących poszczególnych komisji: Zygmunt Łempicki — komisja do spraw propagandy książki w prasie periodycznej; Wacław Borowy - komisja do spraw bieżącej rejestracji bibliograficznej; Stanisław Lam — komisja do spraw księgarstwa sortymentowego; Witold Hulewicz — komisja do spraw przekładów. Komisja do uregulowania spraw przekładów z języków obcych podjęła współpracę z komisją wyłonioną przez Związek Zawodowy Literatów Polskich, czego efektem było porozumienie między Sekcją Tłumaczy Związku Zawodowego Literatów Polskich a PTWK. 


\section{ANKIETA DOTYCZACCA MOTYWÓW KUPOWANIA KSIAZŻEK, LISTY KSIĄŻEK, BONY KSIĄŻKOWE}

RK, chcąc zorientować się, jakie środki promocji książki będą najskuteczniejsze, rozpisała ankietę w sprawie motywacji do jej zakupu. W ramach wprowadzenia pojawił się apel do respondentów: „Odpowiedz, nie zwlekając, na poniższą ankietę »RADY KSIĄŻKI«! Wyniki ankiety stanowić będą podłoże polityki wydawniczej polskiej na okres lat najbliższych. TWOJA ODPOWIEDŹ MOŻE ZAWAŻYĆ NA SZALI! Odpowiedz zatem w interesie kultury polskiej, w interesie bezimiennych rzesz czytelniczych, w interesie własnym" (Sprawozdanie z działalności Rady Książki, 1938, s. 12). W metryczce znalazły się pytania o: płeć, wiek (przedziały: do 18 lat, 18-25 lat, ponad 25 lat), miejsce zamieszkania (miasto, wieś), wykształcenie, zawód. Następnie respondenci mieli określić, czy korzystają z bibliotek (tak/nie) oraz czy kupują książki (ile w roku, za jaką kwotę, jakiego gatunku: beletrystyczne, naukowe). Podstawową kwestią były motywacje, jakimi kierowali się ankietowani przy wyborze publikacji. Otrzymali oni następujące opcje odpowiedzi: nazwisko autora, tytuł książki, jej temat, recenzja (w druku, w radiu), polecenie (księgarza, znajomych, inne), przejrzenie książki, katalog księgarski, ogłoszenie lub prospekt, okno księgarskie, wiadomość z biblioteki, inne motywy. Niepotrzebne odpowiedzi należało skreślić, a w przypadku wybrania kilku opcji uszeregować je według ich znaczenia (ponumerować) (Sprawozdanie z działalności Rady Książki, 1938, s. 12).

Kwestionariusz ankiety został wydrukowany na pocztówce i rozpowszechniony w piętnastu tysiącach egzemplarzy. ZKP rozesłał ankietę (dziesięć tysięcy egzemplarzy) $\mathrm{z}$ dołączonymi do niej pismem przewodnim i apelem o przekazywanie kwestionariuszy klientom do 128 księgarń w 65 miejscowościach. Kolejne pięć tysięcy egzemplarzy starano się rozpowszechnić poprzez biblioteki i władze szkolne. Ankietę potraktowano różnie. Ze sprawozdania RK wiadomo, że „księgarstwo odniosło się do ankiety obojętnie". Dobre wyniki uzyskano natomiast poprzez bezpośrednie zbieranie odpowiedzi, czego podjęli się Irena Jurgielewiczowa i Piotr Górski. Udało się zebrać odpowiedzi jedynie tysiąca osób (Sprawozdanie $z$ działalności Rady Książki, 1938, s. 11-13). Opracowywanie wyników badania przerwała wojna, a zebrany materiał uległ zniszczeniu (Muszkowski, 1947, s. 143).

Do najważniejszych inicjatyw podjętych przez RK należały ponadto listy książek, bony książkowe, akcja „O jedną książkę więcej!” oraz konkursy. Pierwszą z nich było wydawanie specjalnie stworzonych tematycznych list, zawierających zbiór publikacji, które można było kupić na rynku księgarskim. Była to odpowiedź na często sygnalizowany problem braku umiejętności wyboru odpowiedniej książki przez czytelnika: 
Gdy jakieś wydarzenie poruszy opinię publiczną, kiedy zainteresowanie i ciekawość wzbierają z godziny na godzinę, kiedy pora roku, historyczna data, okres świąteczny, tradycja obyczajowa itd. zwracają uwagę ogółu na pewne sprawy i zagadnienia, - niejeden sięgnąłby chętnie po informację czy wyjaśnienie do książki, gdyby wiedział, jak do niej trafić (Ulotki propagandowe, 1938).

RK, chcąc ułatwić jak najszerszej publiczności dotarcie do właściwej książki, a także „Pragnąc przyzwyczaić jak najszersze koła publiczności do szukania pomocy w książce", rozpoczęła wydawanie krótkich list, które miały zawierać 40-60 tytułów dzieł dotyczących aktualnego w danej chwili tematu. Warunkiem umieszczenia danej publikacji w tym zestawieniu była przystępność jej treści i dostępność we wszystkich księgarniach. Wybrane publikacje miały być na poziomie czytelników z ukończoną szkołą powszechną, a trudniejsze pozycje oznaczano gwiazdką. W praktyce liczba tytułów w poszczególnych wykazach wynosiła od 47 do 143.

Określono format, w jakim miały ukazywać się wspomniane listy, zwracając uwagę na ich funkcjonalność. Miała to być jedna karta o wymiarach $25 \times 18 \mathrm{~cm}$, która po złożeniu na pół zmieści się do książki o formacie $8^{\circ}$, zaś złożona na czworo do koperty. W praktyce publikowano listy o objętości od dwóch do czterech stron (od jednej do dwóch kart). W opisach bibliograficznych zamieszczano podstawowe dane: autor, tytuł, oznaczenie wydania, miejsce i rok wydania, informacje o materiale ilustracyjnym, objętość. Zamiast nazwy wydawnictwa stosowano symbole cyfrowe według klucza ZKP 4 (Oznaczanie firm, 1938). Przy tytułach (w tym także przy poszczególnych częściach) umieszczano ceny. Warto zwrócić uwagę, że podawano ceny różnych typów wydań, na przykład bibliofilskich, w różnych oprawach i drukowanych na różnych rodzajach papieru. Na listach znajdowały się rozmaite materiały: książki, roczniki czasopism, mapy, atlasy, plany.

Listy przeznaczone do rozpowszechniania przez księgarnie sortymentowe były zaopatrzone w napis „Do nabycia w księgarni:”, obok którego było miejsce na pieczęć danej placówki. W przypadku zamówień na co najmniej tysiąc egzemplarzy danej listy księgarnie mogły otrzymać je z już nadrukowaną nazwą firmy. Listy były oznaczone znakiem firmowym RK. Umieszczono na nich także adres tej organizacji, miejsce i datę wydania, inicjały osoby opracowującej listę, wydawcę i nazwę drukarni (we wszystkich przypadkach była to Drukarnia M. Arcta). Ceny list dla firm zrzeszonych w ZKP i PTWK wynosiły (łącznie z portem): do 500 egzemplarzy — półtora grosza za egzemplarz; za 1000 egzemplarzy — jeden grosz za egzemplarz. Firmom należącym do RK przysługiwało $10 \%$ rabatu. Za nadruk firmy trzeba było dopłacić po trzy złote od tysiąca egzemplarzy. Próbny,

${ }^{4}$ Oznaczenia te pojawiły się na listach książek RK na próbę po tym, jak ZG ZKP podjął uchwałę o zmianie oznaczeń wydawnictw na cyfrowe. Symbol (stały) składał się z dwu liczb pierwszej zależnej od tego, na jaką literę zaczyna się brzmienie lub nazwa wydawnictwa, oraz drugiej przyporządkowanej danemu wydawnictwu według kolejności wpisywania go na listę skrótów. 
okazowy egzemplarz listy dołączono do numeru 18 „Przeglądu Księgarskiego” z 1938 roku (Ulotki propagandowe, 1938). Organ prasowy księgarzy zawsze powiadamiał o ukazaniu się kolejnej listy (Lista książek nr 7, 1939, nr 12; Na dwudziestolecie, 1938; Styczniowa i lutowa, 1939; Szósta lista książek, 1939; Ulotki propagandowe, 1938). ZKP liczył, że „Pośredniczyć w tym będzie z ochotą każdy księgarz-sortymentysta świadomy swych zadań kulturalnych i własnego interesu" (Na dwudziestolecie, 1938).

Od października 1938 roku do maja 1939 roku RK wydała osiem list książek. W październiku 1938 roku wydano listę nr 1: Ustrój państwa, parlament, wybory (L.Z., 1938b). Jej hasłem przewodnim było: „Uświadomienie polityczne obywateli warunkiem potęgi państwa" (L.Z., 1938b, s. [1]). Zamieszczona na dwóch stronach lista zawierała 47 pozycji, w tym jedenaście trudniejszych, oznaczonych gwiazd$\mathrm{ką}^{5}$. Pierwszy spis spotkał się z dobrym przyjęciem, o czym Rada poinformowała przy okazji przygotowywania kolejnego wykazu, który dotyczył osiągnięć polskiej pracy we wszystkich dziedzinach życia w okresie pierwszego dwudziestolecia po odzyskaniu niepodległości (Na dwudziestolecie, 1938). Na dwudziestolecie (L.Z., 1938a) - lista numer 2 (o objętości dwóch stron) — zawierała 63 pozycje (w tym siedem trudniejszych, wyróżnionych gwiazdką). Wykaz dzieł poprzedzono następującym komentarzem: „Po listę tę sięgnie z zainteresowaniem każdy, bo każdy znajdzie w niej coś dla siebie: podnietę w pracy, pogłębienie wiedzy zawodowej, rozszerzenie widnokręgów umysłowych, tytuł do uzasadnionej dumy narodowej" (L.Z., 1938a, s. [1]). W listopadzie 1938 roku opublikowano listę numer 3 - Wybór wydawnictw gwiazdkowych (P.H., 1938). Na czterech stronach umieszczono 143 pozycje. W przypadku tego zestawienia nie zastosowano oznaczeń gwiazdkowych. Zostało ono podzielone na kategorie: „dla dzieci” (40 pozycji), „dla młodzieży” (65 tytułów) i „dla dorosłych” (38 pozycji). W „Przeglądzie Księgarskim” pojawiła się informacja, że księgarnie z całej Polski zakupiły i rozpowszechniły 14360 egzemplarzy tej listy, a parę tysięcy rozeszło się we Lwowie (Uzupełnienie, 1939). Lista numer 4 (styczeń 1939 roku) - Karnawałowa (W.W., 1939) - poświęcona była „,rozrywkom, przyjemnościom i zabawom, uprawianym wprawdzie w ciągu całego roku, ale tylko w karnawale stanowiącym ośrodek zainteresowań powszechnych" (W.W., 1939, s. [1]). Czterostronicowa lista zawierała 122 pozycje (w tym dziewięć trudniejszych, oznaczonych gwiazdką), które podzielono tematycznie na następujące działy: „Muzyka, taniec i śpiew” (47 pozycji, w tym osiem trudniejszych); „Teatr i kino” (40 tytuły, w tym jeden trudniejszy); „Życie towarzyskie” (25 dzieł); „Dobra kuchnia” (dziesięć pozycji). Na ostatniej stronie wykazu znalazła się reklama subskrypcji dzieł zbiorowych Fryderyka Chopina,

5 Obliczenia własne na podstawie wszystkich list książek wydanych przez RK. Pozycje tomowe i w częściach liczono jako jeden tytuł. 
wydawanych przez Instytut Fryderyka Chopina, a także hasło reklamujące bony książkowe: „Wolny wybór podwaja wartość książki jako podarku, żądajcie więc w księgarniach bonów książkowych" (W.W., 1939, s. [4]). Kolejne listy to: numer 5 (luty 1939 roku) — Sporty zimowe (A.P., 1939b) — pod hasłem „Trzy wyrazy — hasło znane: FIS, zawody, Zakopane" (A.P., 1939b, s. [1]), o objętości trzech stron, zawierająca 71 pozycji w następującym układzie tematycznym: „Sporty terenowe" (46 tytułów) i „Sporty na sali” (25 pozycji); nr 6 (marzec) — Zagadnienia religijne (H.M., 1939) — o objętości czterech stron, na których wskazano 80 pozycji (w przypadku tej listy pojawiło się oprócz spisu więcej informacji dodatkowych, takich jak: tytuły list książek o numerach 1-8, hasło reklamujące bony książkowe RK, pierwsza lista księgarń uczestniczących w obiegu bonów książkowych oraz wyciąg ze statutu RK dotyczący członkostwa); numer 7 (kwiecień 1939 roku) Ogród przy domu (W.P., 1939) — o objętości dwóch stron, na których znalazło się 79 pozycji w układzie tematycznym: „Ogrodnictwo ogólne” (trzynaście publikacji); „Sadownictwo” (16 tytułów); „Warzywnictwo” (22 pozycje); „Ogrodnictwo ozdobne" (28 dzieł); nr 8 (maj 1939 roku) — Dokad pojedziemy na lato? (A.P., 1939a) - o objętości czterech stron, zawierająca 88 pozycji.

Oprócz „Przeglądu Księgarskiego”, publikującego informacje o listach we własnym interesie, można zwrócić uwagę na materiały zamieszczane na przykład na łamach „Obrony Kultury”. Po raz pierwszy informacja na ten temat znalazła się w ostatnim numerze tego periodyku z 1938 roku, gdzie listy książek określono jako pożyteczną inicjatywę RK. Listy były rozpowszechniane także poza księgarniami przez szereg instytucji, między innymi Kuratorium Okręgu Szkolnego Warszawskiego, Bibliotekę Publiczną m.st. Warszawy, Poradnię Biblioteczną ZBP oraz liczne biblioteki (Listy książek, 1938). W 1939 roku w „Obronie Kultury” opublikowano informacje o kolejnych listach, podsumowując: ,,[...] daje nam Rada Książki w tej liście cenny przewodnik dla czytelników, spragnionych wszelkiego typu wskazówek w labiryncie piśmiennictwa współczesnego" (Rada Książki, 1939).

Bony książkowe były jedną z form działania na rzecz propagowania czytelnictwa, którą wykorzystywała rada angielska. Jak donosił „Przegląd Księgarski”, posiłkując się informacją z pisma „Publisher's Circular”, zwyczaj dawania bonów książkowych z okazji uroczystości rodzinnych czy też innych okoliczności był coraz bardziej popularny w Anglii. Obdarowana osoba mogła wymienić bon o określonej wartości na dowolną książkę w dowolnej księgarni. W ciągu roku wydano 227418 bonów (Bony książkowe, 1938; F.B., 1938).

RK w Polsce postanowiła również wykorzystać ten sposób na ożywienie handlu książkami i zachęcić do ich kupowania w charakterze prezentu imieninowego czy gwiazdkowego. Bony były czymś, czego nie stosowano dotąd w Polsce do promocji książki. Miały one ponadto usunąć największą przeszkodę w kupowaniu książki jako prezentu, którą były trudność wyboru oraz obawa, że obdarowany 
posiada już daną książkę. Do bonów przekonywano, opisując ich zalety - między innymi dawały one obdarowanemu możliwość dowolnego wyboru tytułu, można było je łatwo przesłać zwykłym listem oraz stanowiły potrójną pamiątkę dla obdarowanego: ilustrowana karta z życzeniami, dar książkowy, ekslibris do nalepienia na książkę (Bony książkowe, 1938).

Bony książkowe miały przynieść wiele korzyści książce — wzbudzając nową falę zainteresowania nią jako podarunkiem; księgarzom — zwiększając obroty księgarń zrzeszonych w ZKP (toteż podstawowym warunkiem przy wszystkich operacjach związanych z obrotem bonami była możliwość uzyskania przez księgarzy dochodu); a także czytelnictwu — zaszczepiając w najszerszych rzeszach czytelników zamiłowanie do tworzenia biblioteczek prywatnych. Ogólnie liczono na „Wzmożenie czytelnictwa i kultu książki na tle bardziej osobistego do niej stosunku" (Bony książkowe, 1938). Dodatkowym plusem — jeżeli akcja rozwinęłaby się w pełni - miało być to, że księgarze z ZKP będą mogli wykorzystywać bony jako środek bezgotówkowego obrotu wewnętrznego. Według ustalonych zasad mogły one być wymieniane wyłącznie na książki z rabatem o wysokości co najmniej 30\%. W związku z tym z obiegu wyłączone były podręczniki i inne książki szkolne oraz wszystkie wydawnictwa rabatowane poniżej 30\%. RK liczyła także, że wyłączenie z obrotu bonami publikacji z mniejszymi rabatami skłoni wydawców do podwyższenia rabatów na inne publikacje do wspomnianego poziomu. RK miała uzyskiwać $2,5 \%$ z obrotu bonami, którą to kwotę miano przeznaczać na ich wykonanie i wszystkie operacje związane z przydziałem, kontrolą, prowadzeniem rachunku. Według prowizorycznych obliczeń stowarzyszenie zdawało sobie sprawę z konieczności dopłacania do całej akcji: „Rada Książki kalkuluje to przedsięwzięcie na straty, pragnąc przyczynić się do powiększenia obrotów sortymentu w myśl swoich założeń propagandowych" (Bony książkowe, 1938).

W „Przeglądzie Księgarskim” ogłoszono zasady obrotu bonami książkowymi. Były one artystycznie wykonanymi kartami zawierającymi życzenia. Wartość bonu i liczba książek, na które można było go wymienić, była dowolna. Składał się on z trzech odcinków: pierwszy zawierał z jednej strony artystycznie wykonany obrazek, z drugiej życzenia oraz miejsce na datę i podpis ofiarodawcy; na drugim przymocowany był obrazek w postaci ekslibrisu, przeznaczonego do nalepienia na otrzymaną w darze książkę; trzeci stanowił właściwy bon, na którym umieszczono informację o jego wartości (opłacanej przez nabywcę) i który był wymieniany na książki przez obdarowaną osobę. Na tym odcinku księgarnie potwierdzały wartość bonu, datę jego nabycia oraz datę wymienienia go na książki. Dodatkowo znajdowała się tam też instrukcja dla obdarowanej osoby. Każdy bon był opatrzony kolejnym numerem. Mogły one być nabywane i wymieniane na książki tylko w księgarniach należących do ZKP, które po zakończeniu miesiąca kalendarzowego przysyłały do RK rozliczenie ze sprzedanych bonów (numer bonu, wartość), 
a do piętnastego dnia następnego miesiąca powinny przekazać Radzie należność, odliczając sobie przy tym prowizję w wysokości $12,5 \%$. Bon można było realizować w tej samej księgarni, w której się go kupiło, lub w innej na terenie całego kraju, o ile była to placówka uczestnicząca w obiegu lub skłonna zrealizować bon na ustalonych warunkach. W przypadku gdy w danej miejscowości nie było księgarni, można było zrealizować bon za pośrednictwem poczty, ale tylko w księgarni, która go sprzedała (za zwrotem kosztów przesyłki). Placówka, która zrealizowała bon, była zobowiązana do przedstawienia RK zrealizowanych bonów na koniec miesiąca kalendarzowego. Stowarzyszenie wypłacało wówczas należność za zrealizowane bony, począwszy od 20 następnego miesiąca, potrącając przy tym $15 \%$ ich wartości. Rada wystosowała apel do firm wydawniczych o włączenie się do obiegu bonami książkowymi i przyjmowanie ich od księgarń sortymentowych w ramach pokrycia należności (odliczając 15\%) (Zasady obiegu, 1938).

Na początku 1939 roku opublikowano pierwszy wykaz księgarń, które włączyły się do akcji związanej z bonami książkowymi ${ }^{6}$. Było to 29 placówek, zlokalizowanych w Białymstoku, Chorzowie, Ciechanowie, Kaliszu, Katowicach, Lublinie, Lwowie, Łodzi, Ostrowie Wielkopolskim, Poznaniu, Siedlcach, Sierpcu, Warszawie, Wilnie, Zawierciu i Zgierzu ${ }^{7}$ (Bony książkowe, 1939). Z wykazu widać, że reprezentowane były różne ośrodki, w tym mniejsze miasta na prowincji. Warto zauważyć, że spis księgarń zarejestrowanych przez ZKP w 1938 roku obejmował 866 firm (Klukowski, 2008, s. 62-63).

RK wydawała bony w seriach oznaczonych poszczególnymi literami. Pomimo braku szczegółowych informacji można wysnuć tego rodzaju przypuszczenie, ponieważ w marcu „Przegląd Księgarski” poinformował o wypuszczeniu szóstej z kolei serii bonów, oznaczonej literą F. Została ona przygotowana specjalnie na dzień św. Józefa i ozdobiona była portretem marszałka Józefa Piłsudskiego autorstwa Wiktorii Goryńskiej: „Nowa seria bonów przedstawia się pod względem artystycznym równie dodatnio jak serie dawniejsze, a spodziewać się należy, że znajdzie jeszcze liczniejsze zastosowanie w użyciu niż serie poprzednio wydane" (Nowa seria, 1939).

${ }^{6}$ Brak informacji w dostępnych źródłach o kolejnych wykazach.

7 Szczegółowy wykaz księgarń: Białystok - Księgarnia Nauczycielska; Chorzów W. Grzesiewski; Ciechanów - A. Biesiekierska (właściciel E. Sitkiewicz); Kalisz — Księgarnia Polska; Katowice — Księgarnia Katolicka, Tadeusz Mikulski; Lublin — Zdzisław Budziszewski; Lwów - A. Krawczyński; Łódź - S. Seipelt; Ostrów Wielkopolski — Księgarnia Polska; Poznań - Stefan Dippel, Władysław Wilak; Siedlce - Izabela Kapuścińska; Sierpc - M. Kozłowska; Warszawa - Instytut Wydawniczy „Biblioteka Polska”, Drukarnia i Księgarnia św. Wojciecha, Główna Księgarnia Wojskowa, Księgarnia „Verbum”, Księgarnia „Wirginia” (właściciel H. Wirgin), J. Lisowska, J. Przeworski, I. Rzepecki, Sroczyński i Hofman, G. Szylling, Towarzystwo Wydawnicze w Warszawie, TEM; Wilno - Drukarnia i Księgarnia św. Wojciecha, Kazimierz Rutski; Zawiercie - K. Lubcke i S-ka; Zgierz - Al. Lach. 
Okazało się, że reakcje na bony w poszczególnych środowiskach były zróżnicowane. Księgarstwo sortymentowe przychylnie podeszło do nowej formy rozpowszechniania książek, która po zdobyciu popularności mogła powiększyć jego obroty. Propagowanie i wykorzystanie bonów książkowych przez księgarzy było traktowane jako nowa forma pracy i sposób reklamowania książek: „Również za objaw dobrego tonu, za dowód wyższej inteligencji czy oświaty może być uznane w każdej miejscowości korzystanie z bonów książkowych. W małych miastach nawet łatwiej taką metodę wprowadzić niż w miastach większych. Trzeba jednak koło tego trochę się potrudzić, a przede wszystkim zjednać dla sprawy osoby, które mają wpływ na tworzenie się miejscowej opinii publicznej" (Nowe drogi, 1939). Z kolei wydawcy odnieśli się dosyć chłodno do pomysłu bonów. Mimo apeli RK nie włączyli się do akcji, poprzestając na obserwacji, jak sprawdza się w praktyce to rozwiązanie. Głosy publiczności były pozytywne, chwalono pomysł, lecz niezbyt często korzystano z bonów. Prasa początkowo była nastawiona przychylnie do ich wprowadzenia - wyrażała się o nich życzliwie, a czasami nawet entuzjastycznie. Z czasem jednak zaczęły pojawiać się głosy krytyczne wobec tej koncepcji (Nowe drogi, 1939; Za i przeciw, 1939).

Jednym z bardziej kategorycznych przeciwników bonów okazał się Walerian Charkiewicz - wileński publicysta i krytyk literacki. Jego tekst na ich temat, który ukazał się na łamach „Kuriera Bibliofilskiego” (numer z 25 stycznia 1939 roku) (Charkiewicz, 1939), doczekał się nawet komentarza w „Przeglądzie Księgarskim" (Za i przeciw, 1939). Charkiewicz już na początku swojej wypowiedzi zarzucił RK, że skoro na bonie było miejsce na życzenia, to według tej organizacji kupowanie książek musi wiązać się tylko z jakąś wyjątkową okazją. Uważał on, że bony nie spełnią swojego zadania i przytoczył cztery argumenty, by poprzeć swoją tezę. Pierwszym z nich było to, że są one „równoważnikiem pieniądza”. W związku z tym uważał, że nadają się one ewentualnie jako prezent dla dzieci i młodzieży, której lepiej dać bon, a nie gotówkę. Według niego w ogóle nie powinno się go brać pod uwagę jako prezentu dla dorosłych: ,[...] ale niech nam (zajadającym kolacje na cudzy koszt i nie spłacającym długów) ktoś zaproponuje w prezencie kilkanaście złotych, odczujemy to jak policzek!" (Charkiewicz, 1939, s. 1). W odpowiedzi na ten zarzut stwierdzono, że nie zakładano przeznaczania bonów dla wszystkich i ich stosowania w każdej sytuacji. Nie powinno się ograniczać ich tylko dla dzieci i młodzieży, ale na pewno stosować w kręgu rodziny i przyjaciół. Kolejna krytyczna uwaga Charkiewicza to opinia, że bon książkowy „jest sfałszowanym banknotem”. Teza ta została przez niego uargumentowana spostrzeżeniem, że nie było możliwości wymiany bonu na dowolną książkę. Jego zdaniem trudno, żeby osoba kupująca go, a także nim obdarowana, wiedziała, jaki rabat otrzymuje księgarz na konkretne książki, ani czym są ,inne książki szkolne”: 
Więc o przykre nieporozumienie jest niesłychanie łatwo. [...] Szczęśliwy posiadacz bonu czuje się upokorzony, jak człowiek, któremu ktoś podsunął fałszywy banknot i w ten sposób naraził na niewyraźną sytuację. Rzecz oczywista, że po takim doświadczeniu wyrzuci precz przykry bon, albo zwróci ofiarodawcy, dodając ostry komentarz!... (Charkiewicz, 1939, s. 2)

Odpowiadając na tę uwagę, zasugerowano, że ostatecznie można było powiedzieć, że bon nie jest „,pełnowartościowym banknotem”, ale nie jest on fałszywy. RK zdawała sobie sprawę z panujących warunków handlowych, stąd też pomysł na wymianę bonu na książkę-prezent, bo w ówczesnej sytuacji taką transakcję można było w pełni zrealizować. Dwa ostatnie argumenty Charkiewicza nie do końca były powiązane z bonami. Publicysta ten stwierdził, że „Książka jest towarem bez wartości”. Jest ona według niego luksusem, który krótko po zakupie traci na wartości. Udowadniał on także, że „Książka nie ma dla siebie miejsca w nowoczesnych mieszkaniach" (Charkiewicz, 1939, s. 2). W podsumowaniu Charkiewicz stwierdził, że bony nie uratują książki w Polsce. Jego zdaniem potrzebne są bardziej przemyślane i radykalne działania, a przede wszystkim polskie rozwiązania. Pod tekstem pojawiło się hasło: „Propagujmy książkę — ale nie przez »bony«" (Charkiewicz, 1939, s. 2). W odpowiedzi zwrócono uwagę, że RK nie traktowała bonów jako środka do załatwienia wszelkich problemów. Było to jedno z możliwych działań, które miało w jakimś stopniu poprawić sytuację. Stwierdzono, że bony przyniosły korzyści dla małych księgarń, które w przypadku braku książki we własnym asortymencie mogły sprzedać klientom bon i tym samym mimo wszystko ich obsłużyć. W większych księgarniach pojawiało się więcej osób, które przychodziły realizować bony ze względu na duży wybór publikacji (Za i przeciw, 1939, s. 75). Wprowadzenie bonów miało jeszcze jeden niezamierzony skutek. Okazało się, że stały się one inspiracją dla redaktora tygodnika literacko-społecznego „Prosto z Mostu”, Stanisława Piaseckiego, który wystąpił z projektem wprowadzenia bonów kultury. Zakładał on, że $2 \%$ zarobków byłoby wypłacane w bonach, w odcinkach po 50 groszy, do wykorzystania przez pracownika na cele kulturalne (bilet do teatru, kina, na koncert, wystawę, zakup książki). Osoba posiadająca bon, tak zwany ,przymusowy konsument kultury”, według autora projektu powinna mieć dodatkowo zagwarantowane ulgi, na przykład zniżkę na wymienione cele kulturalne o wysokości co najmniej 20\%. Księgarze jednak szybko stwierdzili, że w przypadku książek doprowadziłoby to do upadku księgarń. Dałoby to zatem efekt zgoła odmienny od tego, który przyświecał RK przy wprowadzaniu bonów książkowych (Bony kultury, 1939). 


\section{AKCJA „O JEDNĄ KSIĄŻKĘ WIĘCEJ”I KONKURSY}

Rada postanowiła zorganizować szeroko zakrojoną akcję propagandową pod nazwą „O jedną książkę więcej!”. Początkowo w zapowiedziach akcji był podawany termin 5 marca - 4 kwietnia 1938 roku, ale w późniejszych doniesieniach i sprawozdaniu RK pojawiły się już daty od 12 marca do 4 kwietnia tego samego roku („O jedną książkę więcej”, 1938; Sprawozdanie z działalności Rady Ksiązki, 1938, s. 25; Z „Rady Książki”. „O jedną...”, 1938). Miała to być akcja propagandowa przeprowadzona w prasie i radiu. Jej szczegółowy plan został opracowany w porozumieniu z organizacjami literackimi i księgarskimi. Na początek miał być wydany plakat promujący przedsięwzięcie (Z „Rady Książki”. „O jedną...”, 1938). Rozpisano „cichy konkurs”, zapraszając do udziału w nim sześciu artystów-grafików. W jury zasiedli czterej członkowie zarządu RK oraz delegaci Związku Grafików Polskich, Koła Artystów Grafików Reklamowych, PTWK i ZKP. Posiedzenie tego gremium, któremu przewodniczył August Zaleski, odbyło się 14 stycznia 1938 roku. Wybrano projekt autorstwa znanego grafika Tadeusza Piotrowskiego. Plakaty w dwóch kolorach, o wymiarach $50 \times 70 \mathrm{~cm}$, zostały nieodpłatnie wydrukowane przez Zakłady Graficzne Instytutu Wydawniczego „Biblioteka Polska” w Bydgoszczy, zaś ich rozpowszechnieniem zajął się ZKP. Plakat rozesłano wszystkim członkom tej organizacji, ponadto dołączono go do „Przeglądu Księgarskiego” oraz dostarczono w większej liczbie do wszystkich kół ZKP na trenie Polski - w Katowicach, Krakowie, Poznaniu, Lwowie, Łodzi, Sosnowcu, Wilnie. W ten sposób ogółem rozpowszechniono 2400 egzemplarzy. Polskie Towarzystwo Księgarń Kolejowych „Ruch” S.A. rozkleiło na stacjach kolejowych 600 plakatów, a 200 umieściła na słupach w Warszawie Agencja Telegraficzna. Akcję rozpropagowano również za pomocą odezwy zawierającej wyjaśnienie hasła propagandowego. Wydano także cztery druki z postulatami środowisk literackich i oświatowo-bibliotekarskich, wydawców i księgarzy. Cały materiał zaprezentowano na konferencji prasowej. Efektem były 42 teksty prasowe dotyczące tej inicjatywy. Związek Zawodowy Literatów Polskich zorganizował 29 marca 1938 roku specjalne zebranie, na którym dyskutowano o sprawach książki z różnych punktów widzenia.

W planie akcji propagandowej zostały przewidziane różnorodne formy działania. Oprócz plakatu, ulotek propagujących akcję i promocji w prasie zamierzano również wykorzystać radio. Planowano nadawanie komunikatów RK o przebiegu akcji, organizowanie specjalnych odczytów, pogadanek, dyskusji na tematy związane z książką i ewentualnie przygotowanie konkursu radiowego przy współudziale PTWK. W trakcie trwania akcji miały się odbywać także konkursy: na najlepiej wydaną książkę w 1937 roku; wystaw okiennych firmy Gebethner i Wolff; dla pracowników księgarskich na najlepszą pod względem handlowym 
okładkę książki. Dodatkowo miały być organizowane zebrania z odczytami i późniejszą dyskusją oraz akcje: szkolna, biblioteczna i świetlicowa. Poszczególne organizacje należące do RK miały organizować różne inicjatywy i wspierać działania stowarzyszenia. Nie udało się wykonać pełnego planu akcji, argumentując to kwestiami finansowymi, brakiem ludzi do pracy, a także czynnikami zewnętrznymi. Jedną z przeszkód było nieudzielenie przez Ministerstwo Poczt i Telegrafów zgody na przyznanie ulg taryfowych na przesyłkę materiałów propagandowych i egzemplarzy okazowych w trakcie prowadzenia akcji („O jedną...”, 1938; Sprawozdanie z działalności Rady Ksiązki, 1938, s. 25-31; Z „Rady Książki”, 1938a).

Warto przytoczyć kilka opinii na ten temat, które pojawiły się w prasie obok notek informacyjnych. Ciekawe spostrzeżenia zawarł w swoim tekście, opublikowanym 28 marca 1938 roku na łamach wieczornego wydania „Kuriera Warszawskiego", Kornel Makuszyński. Zwrócił on uwagę na hasło całej akcji, które pojawiło się na afiszu rozklejonym na murach Warszawy: „Afisz jest wybornie pomyślany, lecz napis: »O jedną książkę więcej!« — zdaje mi się nieścisły i mogący wprowadzić pewien zamęt w umyśle niewidocznego człowieka. Afisz powinien wołać »O jedną polską książkę więcej!« [...]” (Makuszyński, 1938, s. 3). Pisarz obawiał się kupowania przez czytelników słabych tłumaczeń, zalegających w koszach ulicznych, co na pewno nie było zamierzeniem inicjatorów akcji. Kolejną kwestią była według niego zbyt skromna prośba o zakup jednej książki: „I nie należy być trwożliwie skromnym. Nie wołać »o jedną książkę więcej« — lecz o dziesięć i dwadzieścia, aby odrobić szpetne zaniedbanie" (Makuszyński, 1938, s. 4). Wymowna była opinia Makuszyńskiego na temat całej akcji: „W tej chwili ci, których przeraża kamienna obojętność wobec książki, starają się przemówić do sumienia tych, co mogą kupić książkę, aby wreszcie ruszyć głaz z miejsca" (Makuszyński, 1938, s. 4).

W związku z akcją do kobiet-czytelniczek zwróciła się na łamach pisma „Kobieta w Świecie i w Domu" Stefania Heymanowa, która podkreślała rolę pojedynczego człowieka i była zdania, że gdyby każdy obywatel Polski w czasie trwania akcji kupił lub przeczytał o jedną książkę więcej, wywołałoby to ożywienie na wszystkich etapach produkcji i obiegu książki. Uważała, że to właśnie kobiety mogły zdziałać najwięcej. Argumentowała tę tezę tym, że to one kupują prezenty, są abonentkami czytelni, a także mają największy wpływ na wyrobienie u dzieci zamiłowania do książki i odpowiednie ukierunkowanie czytelnictwa. Podobnie jak Makuszyński, Heymanowa poruszyła kwestię kupowania i czytania dobrej polskiej literatury, a także kierowania się przy swoich wyborach ocenami zamieszczanymi w pismach literackich (Heymanowa, 1938).

RK ogłosiła konkurs na najlepiej wydaną książkę polską 1937 roku. Należy wyjaśnić, na jakie elementy zwracano przy tym uwagę: „Pojęcie książki najlepiej wydanej obejmuje nie tylko wszystkie czynniki wykonania, jak papier, ma- 
teriał drukarski, odbicie, kompozycję całości, ryciny, okładkę, wzgl. oprawę itp., lecz nadto stopień zharmonizowania szaty wydawniczej z treścią" (Sprawozdanie $z$ działalności Rady Książki, 1938, s. 14). Konkurs w tej edycji dotyczył tylko książek z literatury pięknej i działów pokrewnych, wykonanych całkowicie w kraju w 1937 roku. Zgłoszenia przyjmowano do 31 stycznia 1938 roku, a wyniki miały być ogłoszone najpóźniej do 1 kwietnia 1938 roku. Rada zastrzegała sobie prawo do zorganizowania wystawy prezentującej nadesłane książki, połączonej z plebiscytem dla publiczności. Nagrodą miał być dyplom dla wydawcy i drukarza. W skład sądu konkursowego weszli przewodniczący August Zaleski oraz członkowie: Aleksander Gutry, Bonawentura Lenart, Jan Parandowski, Kazimierz Piekarski, Adam Półtawski i Melchior Wańkowicz. Konkurs został szeroko rozpropagowany — 8 października 1937 roku rozesłano warunki konkursu do dwóch agencji i 24 redakcji warszawskich. Ogółem do rywalizacji przyjęto 96 zgłoszeń od 23 instytucji, firm i osób prywatnych. Na poszczególnych etapach konkursu dokonywano kolejnych selekcji i ostatecznie za najlepiej wydaną książkę polską w 1937 roku w kategorii literatury pięknej i dziedzin pokrewnych uznano Listy Fryderyka Chopina w opracowaniu Henryka Opieńskiego, wydane nakładem Jarosława Iwaszkiewicza i „Wiadomości Literackich” oraz drukowane w Drukarni Narodowej w Krakowie. Dodatkowo wyróżniono jeszcze cztery prace ${ }^{8}$ (Konkurs na najlepiej wydaną, 1937; Sprawozdanie z działalności Rady Książki, 1938, s. 13-25).

Kolejną edycję tego konkursu ogłoszono w 1939 roku; zgłoszenia miano nadsyłać do 1 marca 1939 roku. Tym razem do rywalizacji dopuszczono książki ze wszystkich działów, zaznaczając, że nie mogą to być wydawnictwa bibliofilskie, a tylko publikacje masowo produkowane i przeznaczone do jak najszerszego rozpowszechniania. W skład jury weszli: Jan Parandowski (przewodniczący), Aleksander Gutry, Bonawentura Lenart, Kazimierz Piekarski i Adam Półtawski. Nagrodę otrzymała książka Edwarda Lotha Człowiek przeszłości, wydana przez Książnicę-Atlas (Dwa konkursy, 1939; Konkurs na najlepiej wydaną, 1939).

Kolejną organizowaną przez RK rywalizacją był konkurs na najlepszą pod względem propagandowym okładkę. Udział w nim mogły wziąć jedynie osoby pracujące zawodowo w księgarstwie, a wskazana książka musiała znajdować się wówczas w handlu księgarskim. Zgłaszający musieli uzasadnić swoją propozycję. W sądzie konkursowym zasiedli przedstawiciele Rady i ZKP. Odpowiedzi należało anonimowo nadsyłać do RK w zamkniętej kopercie, opatrzonej godłem oraz napisem „Konkurs okładki”, w terminie do 31 marca 1938 roku. W drugiej kopercie, z tym samym godłem, miano zamieścić imię, nazwisko i adres uczestnika. Na najlepsze odpowiedzi czekały trzy nagrody honorowe. Sąd konkurso-

8 W sprawozdaniu z działalności RK podano szczegółowe etapy konkursu, wyniki głosowania jury, a także uzasadnienie wyboru. 
wy podkreślił, że wyboru najlepszej pod względem propagandowym okładki dokonywano tylko spośród zgłoszonych propozycji i brano pod uwagę sposób uzasadnienia przez osobę, która proponowała daną pozycję. Konkurs miał być ogłaszany w styczniu każdego roku i dotyczyć okładki z roku poprzedniego, a do jury konkursu miał dołączyć przedstawiciel Związku Zawodowego Pracowników Księgarskich w Polsce (dalej: ZZPK) ${ }^{9}$ (Z Rady Książki. Konkurs, 1938; Konkurs Rady Książki, 1938; Sprawozdanie z działalności Rady Książki, 1938, s. 28-31). W 1939 roku informowano o kolejnej edycji konkursu, tym razem na okładkę z 1938 roku. Warunki rywalizacji nie uległy zmianie, nagrodami zaś miały być tym razem książki. W składzie jury mieli zasiadać delegaci PTWK, ZKP, ZZPK, RK (Konkurs dla pracowników, 1939; Dwa konkursy, 1939).

Z okazji osiemdziesięciolecia swego istnienia firma Gebethner i Wolff zorganizowała ogólnopolski konkurs wystaw okiennych. Sąd konkursowy składał się z następujących osób: Adolfa Sturma - przedstawiciela Izby Przemysłowo-Handlowej w Warszawie; radcy Michała Rusinka — przedstawiciela RK; K. Jabłowskiego; Tadeusza Sawickiego — przedstawiciela PTWK; Mieczysława Fuksiewicza — przedstawiciela ZZPK; Feliksa Pieczątkowskiego — przedstawiciela ZKP; Adama Szymańskiego — redaktora „Przeglądu Księgarskiego” i Wacława Gebethnera - przedstawiciela firmy Gebethner i Wolff. Odbyło się kilka zebrań jury w dniach: 24 marca, 29 marca i 6 kwietnia 1938 roku. Do udziału w konkursie zgłosiło się 27 firm, w tym pięć z Warszawy. Wystawy warszawskie komisja oglądała dwukrotnie, a te zlokalizowane poza stolicą oceniano na podstawie fotografii. Ostatecznej ocenie poddano 25 księgarń (w tym pięć warszawskich). Brano pod uwagę następujące kryteria: możliwości techniczne firmy urządzającej wystawę, jej wygląd estetyczny, pomysł, wartość handlową oraz najlepsze zobrazowanie osiemdziesięciolecia działalności firmy Gebethner i Wolff. Sąd konkursowy stwierdził niski poziom wystaw konkursowych, brak pomysłu i niestosowanie się do warunków rywalizacji. Dużo lepsze okazały się wystawy firm zamiejscowych ${ }^{10}$ (Protokół jury, 1938).

Jednym z ostatnich działań RK było zorganizowanie udziału polskich pisarzy w międzynarodowym konkursie na powieść. Na polski konkurs nadesłano 63 zgłoszenia, z czego do ostatniego etapu wybrano pięć propozycji. W jury zasiadali: Kazimierz Czachowski, Zygmunt Łempicki (przewodniczący), Jan Piątek i Leon Piwiński. Pierwszą nagrodę w wysokości tysiąca złotych otrzymała powieść Wacławy Potemkowskiej Gaja; drugą (500 zł) przyznano Wandzie Melcer za Rok w Europie. Powyższe nagrody zostały ufundowane przez Książnicę-Atlas.

${ }^{9}$ W sprawozdaniu z działalności RK podano szczegóły wypowiedzi uczestników konkursu oraz wyniki.

${ }^{10} \mathrm{~W}$ protokole jury znajdują się szczegóły rozstrzygnięcia konkursu — informacje o nagrodzonych osobach i firmach oraz o wysokości nagród. 
Pierwsza nagrodzona powieść miała być wysłana do Londynu i ubiegać się o nagrodę międzynarodową ( 80 tysięcy złotych), zapewniającą dodatkowo ogłoszenie jej drukiem w dziesięciu językach. Konkurs nie został rozstrzygnięty z powodu wybuchu wojny (Międzynarodowy konkurs, 1939; Muszkowski, 1947, s. 144).

RK dbała o wykorzystanie prasy w ramach akcji propagandowej, reklamując swoją działalność oraz zwracając uwagę społeczeństwa na istotne kwestie związane z książką. Od stycznia 1937 roku do maja 1938 roku odbyły się dwie konferencje prasowe. Pierwsze zebranie informacyjne dla prasy zorganizowano pod przewodnictwem Augusta Zaleskiego 6 kwietnia w sali hotelu Bristol w Warszawie. W jego trakcie poinformowano o powstaniu i zadaniach Rady. Referat wyjaśniający cele i misję organizacji wygłosił J. Muszkowski. W spotkaniu tym udział wzięły 33 osoby. Kolejna konferencja odbyła się 9 marca 1938 roku w lokalu Polskiego Klubu Literackiego (obecnych było 28 osób). Na niej referaty w imieniu poszczególnych grup zawodowych wygłosili: Wanda Melcer (literaci), Jan Piątek (nakładcy), Wacław Gebethner (księgarze-sortymentyści). Konferencje odniosły pożądany efekt, przyczyniając się do znacznego zwiększenia liczby tekstów dotyczących RK na łamach prasy. Dokonano wyliczeń wszelkiego rodzaju notatek, wzmianek i artykułów, które ukazały się na temat stowarzyszenia — ogółem było ich 193 (w tym: 93 ogólnie o RK; siedem o podniesieniu poziomu przekładów; 53 o konkursach RK; czternaście o ankiecie o motywach zakupu książek; 42 o akcji „O jedną książkę więcej!") (Rada Książki, 1937c; Sprawozdanie z działalności Rady Książki, 1938, s. 6-7). W powielaniu komunikatów RK, tym samym przyczyniając się do ich rozpowszechnienia, pomagały Państwowe Wydawnictwo Książek Szkolnych, ZKP i Książnica-Atlas (Sprawozdanie z działalności Rady Książki, 1938, s. 5). Zdarzały się jednak w prasie przypadki wprowadzania w błąd potencjalnych odbiorców akcji organizowanych przez RK. Przykładem może być tekst zamieszczony w warszawskim piśmie „Dzień Dobry” z 1939 roku, zatytułowany Karnawałowe bony książkowe o tańcu, o sztuce i o... dobrej kuchni. W nim pomylono z sobą dwie inicjatywy Rady — wydanie listy karnawałowej książek i rozpowszechniania bonów książkowych — tworząc w ten sposób „karnawałowe bony”. Redakcja „Przeglądu Księgarskiego” obawiała się nawet, że ze względu na niekompetencję autora wspomnianego tekstu księgarze będą musieli wyjaśniać klientom, że „bony karnawałowe” w ogóle nie istnieją (Karnawałowe bony, 1939; m., 1939).

\section{ZAKOŃCZENIE}

Jak wynika z zebranego materiału, polska Rada Książki starała się podejmować różne formy działań o charakterze propagandowym, jak: konkursy, wystawy oraz nowe formy rozpowszechniania książek - listy, bony i szeroko zakrojone 
akcje promocyjne. Próbowała ona wykorzystać na większą skalę różne metody promocji książki i czytelnictwa - prasę i radio - które dawały szerszy zasięg oddziaływania. Nie wszystkie przedsięwzięcia udało się w pełni zrealizować, o czym RK poinformowała w sprawozdaniu ze swojej działalności. Przyczynami były między innymi finanse i brak ludzi do pracy. Podjęto próby powołania oddziałów terenowych RK w większych miastach, nawet opracowano dla nich regulamin tymczasowy, ale sprawę odłożono w oczekiwaniu na umocnienie się pozycji głównej Radyl1 (Sprawozdanie z działalności Rady Książki, 1938, s. 6).

Niezaprzeczalną zasługą stowarzyszenia była próba skonsolidowania wszystkich osób i firm związanych z produkcją i rozpowszechnianiem książki, co w dwudziestoleciu międzywojennym, w obliczu ciągłych antagonizmów na rynku książki, było sporym osiągnięciem. Według Jana Muszkowskiego pozytywne nastawienie opinii publicznej i zaufanie do RK było spowodowane tym, że miała ona charakter organizacji społecznej. $Z$ drugiej strony jednak brak stałego budżetu i finanse opierające się na składkach członkowskich czy dobrej woli różnych organizacji uniemożliwiały stowarzyszeniu ciągłość działania. RK nie miała także możliwości egzekwowania od swoich członków konkretnych działań. Na jej obraz w późniejszym okresie działalności negatywnie wpłynęła także rozbieżność interesów. PTWK, które zainicjowało powołanie i kierowało pracami stowarzyszenia, jako zrzeszenie zawodowe przedsiębiorców miało na uwadze interes ekonomiczny. Natomiast RK była organizacją o charakterze ideowym i prowadziła bezinteresowną działalność na rzecz kultury, a w szczególności książki ${ }^{12}$ (Muszkowski, 1947, s. 144).

\section{BIBLIOGRAFIA}

A.P. (Oprac.). (1939a). Dokąd pojedziemy na lato?. Warszawa: Rada Książki.

A.P. (Oprac.). (1939b). Sporty zimowe. Warszawa: Rada Książki.

Ad.L.S. (1936). Rada Narodowa Książki. Przegląd Księgarski, 22(8), 57-58.

11 Brak informacji w dostępnych materiałach, czy kiedykolwiek powrócono do tego pomysłu.

12 Jak pisze J. Muszkowski w tekście z 1947 roku, RK została ponownie powołana po wojnie, tym razem na mocy zarządzenia Ministra Oświaty z dnia 20 września 1945 roku. Jej prace rozpoczęto 19 listopada. Członkami prezydium nowej RK byli: J. Muszkowski, W. Dąbrowska, M. Arct. Rada była jedynie organem inicjującym, opiniującym i koordynującym działania na rzecz książki. Miała zająć się między innymi bibliotekami, wydawnictwami, kształceniem pracowników książki, planowaniem rozwoju książki i jej propagandą. Ze względu na brak uprawnień i środków RK udało się jedynie zapoczątkować kilka zadań, których realizację w późniejszym okresie przejęły powołane do tego instytucje. J. Muszkowski w sprawozdaniu z działalności RK za lata 1945-1947 wspomniał również o całkowitym braku zainteresowania działalnością tej organizacji ze strony ówczesnej prasy. Uniemożliwiło to Radzie szersze rozpropagowanie własnej aktywności i rozwinięcie akcji propagandowej. Zob. też Korczyńska-Derkacz (2012). 
Bony książkowe (1938). Przegląd Księgarski, 24(21), 252.

Bony książkowe. Pierwszy wykaz księgarń (1939). Przegląd Księgarski, 25(2), 14.

Bony kultury (1939). Przegląd Księgarski, 25(6), 50-51.

Charkiewicz, W. (1939). Bony książkowe. Kurier Bibliofilski, 2(1(5)), 1-2.

Dwa konkursy (1939). Przegląd Księgarski, 25(4), 34.

F.B. (1938). Bony książkowe w Anglii. Przegląd Księgarski, 24(9), 93.

(F.B.) (1937). Film o książce. Przegląd Księgarski, 23(9), 92.

H.M. (Oprac.). (1939). Zagadnienia religijne. Warszawa: Rada Książki.

Heymanowa, S. (1938). O jedną książkę więcej. Kobieta w Świecie i w Domu, 14(7), 35.

Karnawałowe bony książkowe o tańcu, o sztuce i o... dobrej kuchni (1939). Dzień Dobry, 9(31), 8.

Klukowski, B. (2008). Księgarstwo i zawód księgarza w Polsce. Publikacja przygotowana z okazji stulecia powstania Związu Księgarzy Polskich. Warszawa: Wydawnictwo Stowarzyszenia Bibliotekarzy Polskich.

Konkurs dla pracowników księgarskich (1939). Przegląd Księgarski, 25(7), 70.

Konkurs na najlepiej wydaną książkę (1937). Przegląd Księgarski, 23(19), 191.

Konkurs na najlepiej wydaną książkę (1939). Przegląd Księgarski, 25(16), 201.

Konkurs Rady Książki na okładkę najlepszą pod względem propagandowym (1938). Przegląd Księgarski, 24(11), 126.

Korczyńska-Derkacz, M. (2012). Działalność Rady Książki w Polsce (1945-1947). Annales Universitatis Paedagogicae Cracoviensis. Studia ad Bibliothecarum Scientiam Pertinentia, 10, 40-58.

L.Z. (Oprac.). (1938a). Na dwudziestolecie, Warszawa: Rada Książki.

L.Z. (Oprac.). (1938b). Ustrój państwa, parlament, wybory. Warszawa: Rada Książki.

Lista książek nr 7 (1939). Przegląd Księgarski, 25(12), 140.

Listy książek. Pożyteczna inicjatywa Rady Książki (1938). Obrona Kultury, 1(7), 3.

m. (1939). Groch z kapustą. Przegląd Księgarski, 25(4), 34.

Makuszyński, K. (1938). O jedną książkę więcej. Kurier Warszawski, 118(86), 3-4.

Międzynarodowy konkurs na powieść (1939). Przegląd Księgarski, 25(12), 146.

Mortkowicz, J. (1926). Rada Narodowa Obrony Książki Polskiej. Przegląd Księgarski, 12(21), 404-409.

Muszkowski, J. (1947). Rada Książki. Przegląd Biblioteczny, 13(1-2), 141-155.

Muszkowski, J. (1951). Życie książki. Kraków: Wiedza — Zawód — Kultura Tadeusz Zapiór.

Na dwudziestolecie (1938). Przeglad Księgarski, 24(19), 229.

Nowa seria bonów książkowych (1939). Przegląd Księgarski, 25(9), 95.

Nowe drogi (1939). Przegląd Księgarski, 25(5), 38, 40.

„O jedną książkę więcej”. Akcja propagandowa „Rady Książki” (1938). Przegląd Księgarski, 24(4), 34.

Oznaczanie firm wydawniczych w katalogach i bibliografiach księgarskich (1938). Przegląd Księgarski, 24(18), 217-218.

P. (1927). Rada Narodowa Książki w Londynie. Przegląd Księgarski, 13(5), 123.

P.H. (Oprac.). (1938). Wybór wydawnictw gwiazdkowych. Warszawa: Rada Książki.

(PIL) (1938). Narodowe targi książkowe w Anglii. Przegląd Księgarski, 24(20), 244.

Piotrowski, T. (1938). O jedną książkę więcej. [Afisz]. Kraków: Rada Książki.

Protokół jury ogólnopolskiego konkursu wystaw okiennych poświęconego wydawnictwom Gebethnera i Wolffa z okazji 80-lecia firmy (1938). Przegląd Księgarski, 25(8), 86-87.

Rada Książki (1939). Obrona Kultury, 2(3), 16.

Rada Książki (1937a). Przegląd Biblioteczny, 11(1-2), 66-67.

Rada Książki (1937b). Przegląd Księgarski, 23(3), 16-17.

Rada Książki (1937c). Przegląd Księgarski, 23(7), 70. 
Rada Narodowa Książki w Anglii (1927). Przegląd Księgarski, 13(15-16), 361.

Rada Związku Bibliotekarzy Polskich (1938). Przeglad Biblioteczny, 12(1), 75-77.

Sprawozdanie z działalności Rady Książki w okresie od stycznia 1937 r. do maja 1938 r. (1938).

Warszawa: Rada Książki.

Sprawozdanie Zarządu Głównego ZKP z działalności w roku 1936 (1937). Przegląd Księgarski, 23(7), 53-57, 58-62, 64-65.

Statut Stowarzyszenia „Rada Książi” (1937). Warszawa: Rada Książki.

Styczniowa i lutowa listy książek (1939). Przegląd Księgarski, 25(4), 34.

Szósta lista książek (1939). Przegląd Księgarski, 25(9), 94-95.

Ulotki propagandowe Rady Książki (1938). Przegląd Księgarski, 24(18), 216.

Uzupełnienie (1939). Przegląd Księgarski, 25(5), 47.

W.P. (Oprac.). (1939), Ogród przy domu, Warszawa: Rada Książki.

W.W. (Oprac.). (1939). Karnawałowa. Warszawa: Rada Książki.

Z „Rady Książki” (1938a). Przegląd Księgarski, 24(1-2), 14.

Z Rady Książki (1938b). Przegląd Księgarski, 24(13-14), 154.

Z Rady Książki. Konkurs okładki najlepszej pod względem reklamowym (1938). Przegląd Księgarski, 24(5), 45.

Z „Rady Książki”. „O jedną książkę więcej” (1938). Przegląd Księgarski, 24(3), 22.

Za i przeciw (1939). Przegląd Księgarski, 25(8), 74-75.

Zasady obiegu bonów książkowych (1938). Przegląd Księgarski, 24(21), 253-254.

MONIKA OLCZAK-KARDAS

\section{THE ACTIVITY OF THE COUNCIL OF BOOKS IN POLAND IN THE YEARS 1937-1939}

\section{Summary}

The Council of Books - a society intended to promote Polish books in the country and abroad, promoting readership among the population, and a culture of books - was active in Poland in the years 1937-1939. The goal of the following piece is to present its activity and in particular its work methods. To aid in the collection and processing of materials, the source analysis method and the analysis and critique of written text. A wide range of actors representing various parts of the literary community were involved in creating the Council of Books. In order to to identify the problems which existed in the book market at that time, the Council called up special commissions, and a survey was created to explore the rationale of book choices. The main activities initiated by the Council of Books were the publishing of theme-based list of books, intended to help (customers) in choosing books. Another policy was the creation of book vouchers, which were intended to rejuvenate the the book market and promote the buying of books. The ad campaign „One more book!" was organised from March 12th - April 4th, 1938. It was supposed to be broad propaganda campaign, conducted via printed media and the radio. Various forms of advertising were used: posters informing customers about the ad campaign, fliers explaining the details of the ad campaign, press conferences, contests (in particular, a contest for the best-produced Polish book of 1937, a contest for the cover with the best propaganda value in 1937). The Council of Books was not able to realise all its planned undertakings. The reason for this were financial problems, along with a lack of involvement of sufficient numbers of people. An unquestionable positive leg- 
acy of the council was the attempt to consolidate all the individuals and companies involved with production and distribution of books, which was a significant achievement given all the challenges faced in the book market at the time.

KEY WORDS: Council of Books, 2nd Polish Republic, book, book propaganda, readership, bookselling, publishing market, book market, Polish Association of Publishers, Society of Polish Booksellers 